\title{
A formação educacional das crianças na Antiguidade Tardia: João Crisóstomo e a defesa da escola monástica
}

\author{
The educational training of children in Late Antiquity: \\ John Chrysostom and the defense of the monastic school
}

\author{
Gilvan Ventura da Silva*
}

\begin{abstract}
Resumo: Neste artigo, pretendemos examinar a proposta de formação educacional das crianças formulada entre 380 e 386 por João Crisóstomo, quando ocupava o cargo de diácono da congregação de Antioquia, após ter vivido por seis anos na companhia dos monges do Monte Sílpios, ocasião em que travou contato in loco com a vida monástica. Para tanto, analisamos os argumentos de João contidos na obra Adversus oppugnatores vitae monasticae, na qual o autor, ao mesmo tempo que empreende uma defesa incondicional do monacato, estabelece os princípios de uma pedagogia cristã segundo a qual os pais deveriam confiar a educação de seus filhos, não aos rétores ou gramáticos, mas aos monges, os únicos habilitados a fazer deles indivíduos honrados, o que revela o seu estranhamento com a escola greco-romana, cujo currículo era baseado no aprendizado da retórica e da oratória, pedras angulares da paideia, mas tidas por ele como inúteis.
\end{abstract}

\begin{abstract}
In this article, we intend to examine the John Chrysostom's ideas regarding the educational formation of children between 380 and 386, when he was a deacon of the Antiochene congregation, after living for six years in the company of the monks who dwelled on the Mt. Silpius. In such occasion he could acquire in loco knowledge about the monastic lifestyle. In order to do that, we analyse the Chrysostom's arguments exposed in Adversus oppugnatores vitae monasticae, a treatise in which the author not only stands up for the monasticism, but settle the tenets of a Christian pedagogy according to which the parents should let the formation of their children in the monks' hands instead of sending them to the school of the rhetors and grammarians, whereas the monks were the only ones capable of converting children into honourable men. Eventually, the Chrysostom's ideas reveal a struggle against the classical school, whose curriculum was based on rhetoric and oratory, pivots of the paideia, but considered useless by him.
\end{abstract}

Palavras-chave: Antiguidade Tardia. João Crisóstomo. Infância. Educação cristã. Monacato.

\footnotetext{
* Professor Titular de História Antiga da Universidade Federal do Espírito Santo (Ufes). Doutor em História pela Universidade de São Paulo, bolsista produtividade 1-C do CNPq e pesquisador do Laboratório de Estudos sobre o Império Romano (Leir). No momento, executa o projeto Migração, movimento e desordem na cidade pós-clássica: Antioquia e os efeitos da dinâmica populacional (356-397 d.C.).
} 


\section{A História da Infância na Antiguidade, um domínio em construção}

$\mathrm{N}$ os últimos anos, mediante a consolidação de um paradigma de interpretação da História que, por um lado, não se contenta mais em descrever apenas estruturas sem rosto e, muitas vezes, sem vida, e que, por outro, tende a problematizar - e mesmo a confrontar - o peso excessivo conferido a determinados agentes históricos em detrimento de outros, os historiadores têm sido cada vez mais compelidos a iluminar uma pletora de indivíduos e/ou grupos amiúde ignorados nas narrativas convencionais sobre o passado, o que deu margem à emergência de subáreas do conhecimento histórico devotadas ao estudo de todas aquelas personagens às quais não se costumava dispensar maior atenção, a exemplo da História "vista de baixo" (SHARPE, 1992), que enfatiza, sob uma ótica marxista, o modus vivendi dos estamentos sociais inferiores (escravos, operários, camponeses); da História dos Marginais, ou seja, daqueles colocados à margem do sistema ou da "boa sociedade" e que, por isso mesmo, foram sempre tratados com desprezo (hereges, hippies, delinquentes, cf. SCHMITT, 1990); e da Micro História, com sua predileção pelos anônimos e pelos esquecidos, cuja trajetória somente pode ser reconstituída às custas de um laborioso trabalho de prospecção documental (VAINFAS, 2002). Decerto, poderíamos incluir, neste inventário, a História das Mulheres, um domínio de investigação que, não obstante o extraordinário avanço obtido nas últimas décadas, não foi ainda capaz de romper com a tendência de se privilegiar os atores masculinos na narrativa histórica, como assinalamos, em certa ocasião, ao demonstrar como os livros didáticos de História são evasivos, seletivos ou mesmo preconceituosos ao lidar com a figura feminina, em geral muito maltratada (SILVA, 2009). Todas essas inovações têm ensejado, ao longo do tempo, uma renovação sem precedentes na maneira pela qual os historiadores elegem seus objetos, que se revelam, na atualidade, cada vez mais sofisticados e diversificados. Cumpre destacar, no entanto, que tais inovações são muitas vezes absorvidas com certo descompasso pelos profissionais dedicados ao estudo da Antiguidade, e aqui nos referimos não apenas aos historiadores, mas igualmente aos arqueólogos, na medida em que a Arqueologia Clássica tem cada vez mais se consolidado como uma disciplina indispensável para o conhecimento das sociedades antigas. Em todo caso, historiadores e arqueólogos têm buscado, com uma frequência cada vez maior, expandir o campo de investigação acerca dos antigos, incorporando à sua agenda novos temas, alguns francamente desafiadores, o que exige maior cuidado não apenas no sentido de valorizar indícios que costumavam ser ignorados, mas também de revisitar, sob outra perspectiva, evidências já conhecidas, cuja interpretação parecia estabelecida em definitivo. 
Um esforço intelectual dessa natureza é o que realiza Robert Knapp (2011), numa obra provocativa intitulada Invisible Romans, na qual o autor, recorrendo a uma vasta seleção de fontes e a contrapelo do volume maciço de informações sobre o estilo de vida das categorias superiores da sociedade imperial, busca lançar luz sobre os atores "invisíveis", as pessoas comuns que constituíam a maioria absoluta da população do Império Romano: mulheres humildes, pobres, escravos, libertos, soldados, prostitutas, gladiadores, bandidos e piratas. A iniciativa de Knapp, ao se distanciar de uma abordagem centrada nas elites romanas, é, sem dúvida, notável não apenas por aquilo que integra à narrativa, mas também pelo que deixa de fora, por aquilo sobre o qual silencia. Nos referimos aqui, em particular, às crianças, talvez o segmento mais invisível dentre todos os invisíveis da Antiguidade. A raiz dessa exclusão não deve ser, em absoluto, atribuída a mero capricho ou opção, malgrado o fato, sobejamente conhecido, de que o estudo dos processos históricos - assim como dos fenômenos físicos, químicos e biológicos - resulta sempre de uma seleção operada pelo pesquisador, que não tem condições de reter, nos limites de um texto, "tudo o que aconteceu no passado". Pelo contrário, o silêncio acerca das crianças numa obra de 2011 dedicada aos romanos "invisíveis" apenas atesta o caráter recente e até certo ponto experimental desse domínio, cujo florescimento pode ser datado da última década. As crianças, a bem da verdade, nunca foram completamente preteridas pelos historiadores, que de quando em quando lhes dispensavam alguma atenção. Os estudos modernos sobre o estatuto social da infância e sua importância ao longo da História têm início na passagem do século XIX para o XX, no âmbito da História da Educação, momento em que, na Europa, nos Estados Unidos e em outros países das Américas, os sistemas nacionais de ensino começavam a ser construídos (VUOLANTO, 2017, p. 12). Ainda que valorosos, tais estudos, ao se deterem na análise dos procedimentos pedagógicos por meio dos quais as crianças deveriam ser convertidas em adultos, alinhando-se assim a uma visão eminentemente prescritiva da infância, não enfocavam a criança per se nem buscavam compreendê-la à luz das variações espaço-temporais, o que resultava numa concepção ilusória segundo a qual as crianças do passado e as do presente compartilhariam a mesma identidade, concepção esta que se manteve em voga por décadas a fio, até que, na década de 1960, o trabalho pioneiro de um historiador diletante, como foi Philipe Ariès, alterou radicalmente o modo como a infância era tratada nos círculos acadêmicos.

Não obstante as inúmeras críticas que recebeu, a obra L'enfant et la vie familiale sous l'Ancien Régime, publicada em 1960, representou um autêntico turning point nos 
estudos sobre o tema. ${ }^{2} \mathrm{Na}$ realidade, não seria um completo exagero afirmar que, com essa obra, Ariès não apenas estabelece um novo approach para a História da Infância, mas, antes, funda a própria disciplina. Como salienta Lebrun (2011, p. 232-233), L'enfant et la vie familiale sous l'Ancien Régime, que consumiu mais de uma década de trabalho, representa um estudo pioneiro, uma vez que, à época, eleger a criança e a família como objetos de análise histórica era uma autêntica novidade. ${ }^{3}$ Antes de Ariès, outros historiadores já haviam se interessado pelo casamento, pela família e pela situação da mulher na França do Ancient Régime, mas sob uma perspectiva jurídica e anedótica e sem incluir a infância, carência que o autor foi muito bem-sucedido em reparar, como comprova o imediato sucesso de sua obra, que lhe abriu as portas dos círculos acadêmicos em terra natal e no estrangeiro, tendo Ariès se tornado um dos mais conhecidos historiadores franceses nos Estados Unidos e em outros países. Seu trabalho despertou ao mesmo tempo interesse e polêmica, pois os medievalistas não pouparam críticas ao autor por datar, entre os séculos XVII e XVIII, o surgimento do amor materno, negando assim a experiência medieval da maternidade, críticas estas que Ariés buscou responder no prefácio da segunda edição, publicada em 1973. Em todo caso, não resta dúvida que L'enfant et la vie familiale sous l'Ancien Régime é um marco dos estudos sobre a História da Infância, tendo estimulado gerações de pesquisadores que, inspirados por Ariès, passaram a refletir sistematicamente sobre as crianças e as famílias do passado. Para tanto, foram indispensáveis as contribuições advindas da Demografia, da História do Direito e da História da Educação (LAES; VUOLANTO, 2017, p. 3), cujos investigadores passam a se interessar cada vez mais pela família e pela infância.

Num primeiro momento, no entanto, o paradigma empregado ainda era, por assim dizer, normativo, na medida em que as crianças eram estudadas à luz daquilo que os adultos pensavam sobre elas, considerando-se a infância uma fase preparatória e antecipatória da vida adulta. Submetida a uma pletora de regras que visavam, por um lado, a fazer dela um ser humano pleno e, por outro, a integrá-la de modo satisfatório ao convívio dos adultos, a criança costumava ser esvaziada de qualquer protagonismo, sendo tratada como uma figura eminentemente passiva, como vemos em boa parte dos estudos conduzidos sob inspiração dos códigos jurídicos ou dos tratados pedagógicos.

\footnotetext{
${ }^{2}$ A edição da obra de Ariès por nós consultado é aquela publicada, no Brasil, em 1978, com o título História Social da criança e da família.

${ }^{3}$ O pioneirismo de L'enfant et la vie familiale sous l'Ancien Régime não se restringe ao tema por ela tratado, mas inclui também o ecletismo das fontes exploradas, pois Ariès, ao contrário da maioria dos historiadores de ofício de seu tempo, não partiu de um conjunto bem estabelecido de documentos para empreender seu estudo, mas lançou mão de múltiplas fontes, para além dos textos pedagógicos: correspondências, registros contábeis, dados demográficos e imagens contidas em lápides, gravuras, pinturas (LEBRUN, 2011, p. 234).
} 
Não obstante a validade desse enfoque, as reflexões sobre a História da Infância, na atualidade, têm buscado cada vez mais recuperar aquilo que os pesquisadores definem como agência infantil, ou seja, a contribuição das próprias crianças para o seu processo de socialização, na medida em que internalizam ou mesmo rejeitam esta ou aquela norma e, nesse movimento, transformam e renovam o patrimônio cultural do qual são herdeiras, o que nos leva a estudar as crianças por elas mesmas, como seres portadores de desejo e vontade e, por isso mesmo, capazes de intervir nos rumos do seu aprendizado e do seu amadurecimento (VUOLANTO, 2017, p. 12). Por óbvio, uma abordagem como essa encontra-se, à partida, condicionada pela qualidade das fontes à disposição do historiador, pois, em muitos casos, é difícil - senão impossível - recuperar a voz e a ação das próprias crianças, que poucos registros deixaram de si mesmas. Seja como for, o mais importante é não tomar as declarações e testemunhos dos adultos sobre as crianças como uma descrição objetiva do universo infantil, mesmo cuidado que, mutatis mutandis, devemos ter quando se trata das mulheres, outra categoria que, durante séculos, foi marcada pelo silêncio e pelo anonimato.

Quando nos dispomos a investigar a situação das crianças no Império Romano, é preciso, logo de início, atentar para o fato de que, em decorrência da baixa expectativa média de vida (entre 30 e 35 anos), as crianças e jovens representavam uma parcela expressiva da sociedade greco-romana, pois cerca de $1 / 3$ da população se encontrava abaixo dos quinze anos de idade (LAES; VUOLANTO, 2017, p. 2). Muito embora, na atualidade, os rapazes e as moças sejam, a partir dos doze anos, qualificados como adolescentes, fazendo parte, assim, de uma categoria intermediária entre a infância e a idade adulta, essa distinção, na Antiguidade, era muito mais tênue do que é hoje, pois, a rigor, não existia a fase da adolescência, mas uma infância prolongada e, em seguida, a idade adulta. A despeito de os códigos jurídicos romanos fixarem o fim da infância aos doze anos para as meninas e aos catorze anos para os meninos, a realidade era bem mais complexa. A rigor, em Roma, caso viesse a contrair matrimônio, uma menina poderia ser considerada adulta aos dez anos de idade, ao passo que um menino somente se tornaria adulto ao portar a toga virilis, o que poderia ocorrer a qualquer momento no intervalo entre os treze e os dezoito anos. No Egito romano, por sua vez, o ingresso na idade adulta era assinalado pela epikrisis, quando, aos treze ou catorze anos, as crianças da elite recebiam autorização para frequentar o ginásio e se submetiam à taxação (LAES; VUOLANTO, 2017, p. 5). Contudo, para além de todas essas variações, um traço comum da infância era a dependência da criança diante da patria potestas, condição que, segundo o 
Código Teodosiano, poderia se estender até os 25 anos de idade. ${ }^{4}$ Nesse sentido, os filhos que permanecessem por mais tempo sob a tutela dos pais alcançariam a maioridade muito mais tarde em comparação àqueles que houvessem contraído matrimônio.

Na opinião de Caseau (2017, p. 219), a infância, no Império Romano, era uma etapa da vida bastante extensa, indo do nascimento até os 18-20 anos, razão pela qual não deixa de ser surpreendente a pouca adesão dos pesquisadores ao estudo da História da Infância na Antiguidade. É bem possível que alguns atribuam tal situação à carência de fontes de informação adequadas sobre as crianças e o universo infantil. Uma justificativa como essa, embora plausível, não possui, no entanto, validade universal. A bem da verdade, quando se trata de investigar as crianças por elas mesmas, suas ações e seus testemunhos, nos encontramos, de fato, em terreno movediço, dada a escassez de evidências, o que torna os historiadores, em larga medida, dependentes do aporte da cultura material, que, por sua vez, também possui limitações. Quando mudamos o eixo da investigação para o exame das visões acerca da infância, a quantidade de informações disponíveis revela-se bem maior, mas distribuída de maneira desigual no tempo e no espaço. Todavia, um corpus literário pródigo para o estudo das representações da infância no Império Romano é constituído, sem dúvida, pelos textos cristãos, em particular no que diz respeito à formação espiritual dos meninos e meninas, pois o cristianismo, desde o seu surgimento, foi uma crença que reservou um lugar especial para as crianças na ekklesia, em conformidade com os ensinamentos de Jesus que, no Evangelho de Mateus (19, 14), declara: "deixai as crianças e não as impeçais de vir a mim, porque delas é o Reino dos Céus".

De acordo com Leyerle (2013), o cristianismo, devido à sua ênfase sem precedentes nos acontecimentos do dia a dia, nos usos e costumes cotidianos, muitos deles compartilhados por pessoas comuns, assunto que não costumava atrair o olhar dos autores pagãos, quase sempre preocupados em descrever o comportamento da elite, seus valores e atitudes, nutrindo assim pouco interesse por aquilo que fazia ou pensava o vulgus ou o plethos, em muitas ocasiões trouxe a primeiro plano setores da existência descritos com parcimônia ou mesmo ignorados pelas fontes antigas, a exemplo das crianças, personagens que abundam na literatura cristã dos primeiros séculos. De fato, pregadores, apologistas e professores cristãos se dedicaram, desde o início, a refletir sobre a maneira pela qual meninos e meninas deveriam ser instruídos no conhecimento da Boa Nova e das Escrituras e sobre o papel dos pais na educação dos filhos, o que os levou a lançar as bases daquilo que poderíamos definir como Christon paideia, ou seja, uma

\footnotetext{
${ }^{4}$ Embora 25 anos fosse o limite jurídico da maioridade, Constantino, numa lei promulgada entre 321 e 324, autoriza a emancipação de pessoas de vinte anos que apresentem "caráter honorável", a fim de que possam gerir o patrimônio familiar (C. Th., 2, 17, 1).
} 
proposta pedagógica que, a despeito dos seus contornos extremamente fluidos e da sua absoluta falta de sistematização, ao menos até a época tardia, tinha por finalidade definir as diretrizes de como os cristãos deveriam ser socializados, reflexão que acompanhou pari e passu a fixação de um modelo parental calcado nos laços filiais entre Jesus, Maria e José, a Sagrada Família. Além do cuidado com a instrução das crianças segundo os preceitos evangélicos, os autores cristãos se valeram também, na formulação de seus argumentos, de inúmeros exemplos extraídos da realidade infantil, fazendo referência, em suas obras, a jogos, brincadeiras, sentimentos e atitudes próprias da infância. Isso não equivale a afirmar, no entanto, que o papel desempenhado pelas crianças tenha experimentado alterações substantivas devido ao surgimento do cristianismo, uma vez que mesmo a criança cristã continuava sob tutela direta do pai até se casar ou alcançar a maioridade. Em se tratando de famílias com menos recursos, as crianças sempre constituíram uma reserva de mão de obra indispensável ao funcionamento da unidade doméstica, em particular nas zonas rurais. Ademais, elas eram a garantia de que os pais seriam amparados na velhice e de que a família não se extinguiria. Ainda que o cristianismo não tenha produzido qualquer revolução no modo como os antigos encaravam a infância, não é menos verdade que, em determinadas circunstâncias, ele foi capaz de proporcionar às crianças e jovens novas oportunidades numa sociedade na qual a autoridade patriarcal era exercida com rigor, a exemplo da greco-romana. Nos referimos aqui à possibilidade de uma criança abraçar, por decisão familiar ou mesmo por iniciativa própria, a carreira sacerdotal e/ ou monástica, o que, sem dúvida, Ihe permitiria o acesso a novas experiências longe do controle paterno. Uma vez tendo optado por viver num mosteiro, a criança, em geral, ingressava em outra realidade e se desconectava dos vínculos familiares, o que nos leva a discordar de Vuolanto (2014, p. 444), para quem o cristianismo não teria aberto novas perspectivas às crianças do Império.

À luz dessas considerações, pretendemos, neste artigo, discutir a proposta de formação educacional das crianças formulada por João Crisóstomo, um dos mais influentes Padres da Igreja, mas nossa investigação não compreenderá todas as fases da carreira do autor, um dos mais prolíficos - se não o mais prolífico - de toda a literatura grega antiga, uma vez que João, em mais de uma oportunidade, se ocupou da correta educação dos cristãos e da responsabilidade dos pais neste processo, como é possível constatar por meio do De inani gloria, um tratado pedagógico da década de 390 que tivemos a oportunidade de estudar em certa ocasião (SILVA, 2010). Nosso olhar se desloca para outro momento da vida de João, ou seja, para o período compreendido entre 380 e 386, anos em que atuou como diácono da igreja de Antioquia, antes de ser ordenado presbítero, a fim de examinar os argumentos empregados pelo autor em favor de um 
projeto pedagógico cristão, num contexto de enfrentamento com os princípios da cultura clássica, vale dizer, com o currículo escolar tradicional, baseado no aprendizado da retórica e da oratória, disciplinas que constituíam a pedra angular da paideia ou humanitas, da formação educacional dos membros da elite greco-romana na época imperial.

O interesse de João Crisóstomo pelos fundamentos da educação cristã não derivava tão somente de uma preocupação de natureza pedagógica, ou seja, não decorria apenas de uma inquietação do diácono quanto à maneira pela qual as crianças cristãs deveriam ser educadas por suas famílias, mas encontrava-se conectado a uma defesa intransigente dos benefícios da vida monástica, o que é bastante compreensível, tendo em vista que sua ordenação como diácono, em 380, ocorreu cerca de dois depois de sua descida do Monte Sílpios, onde havia se iniciado no ascetismo. ${ }^{5}$ Após seis anos de convivência com os monges da montanha, João decide renunciar à vida monástica, num momento em que Melécio, seu mentor espiritual e um dos líderes dos nicenos de Antioquia, depois de passar uma temporada no exílio por determinação de Valente, estava de volta à cidade. Em 378 ou 379, quando do retorno, João toma conhecimento de que os monges do norte da Síria estariam sendo duramente reprimidos pelos chefes das famílias locais, insatisfeitos com a atração exercida pelo monacato sobre as crianças e jovens. Ameaçados de se virem privados, de um momento para o outro, da companhia dos filhos, para os quais projetavam um futuro de sucesso nas fileiras da administração pública, os pais não hesitavam em confrontar os monges, recorrendo, por vezes, à violência, o que suscita a indignação do autor.

A fim de expor sua opinião sobre o assunto, João decide, então, redigir o Adversus oppugnatores vitae monasticae (Contra os detratores da vida monástica), um tratado cuja elaboração remonta aos anos em que atuou como diácono da congregação de Antioquia, ou seja, entre 380 e $386 .{ }^{6}$ Nele, não se contenta em empreender uma defesa enfática da vida monástica, mas busca convencer os pais de que a melhor formação que podem ofertar aos filhos encontra-se no interior dos mosteiros e não nos bancos da escola grecoromana, uma vez que a filosofia - o estilo de vida - dos monges seria superior àquela ensinada pelos professores pagãos. Desse modo, mesmo que seu objetivo não tenha sido

\footnotetext{
${ }^{5}$ O ascetismo, ao menos em âmbito cristão, se caracterizava por uma notável transformação corporal, no decorrer da qual seus praticantes, mediante a renúncia a hábitos e comportamentos tidos como próprios da condição humana, a exemplo do ato de dormir, comer e copular, buscavam antecipar, sobre a Terra, o corpo místico dos seres celestiais, o que favorecia a comparação entre os ascetas e os anjos (KRAWIEC, 2008, p. 775).

${ }^{6}$ Infelizmente, não temos condiç̃̃es de definir com exatidão a data em que o Adversus oppugnatores teria sido escrito. Hunter (1988, p. 41) propõe que sua redação deva ser fixada entre 378, quando do retorno de João a Antioquia, e 386, ano em que foi ordenado presbítero por Flaviano, opinião compartilhada por Liebeschuetz (2011, p. 142). Festugière (1955, p. 192), por sua vez, sugere o intervalo entre 383 e 386 para a composição da obra. Tendo em vista os distintos pontos de vista, preferimos seguir a estimativa de Kelly (1995, p. 51 et seq.), para quem o Adversus oppugnatores foi escrito durante o diaconato de João Crisóstomo.
} 
o de propor a fundação de qualquer instituição de ensino gerida pelos monges, João Crisóstomo pode ser a justo título considerado um entusiasta das escolas monásticas que, em pouco tempo, surgiriam no Ocidente e no Oriente. Acreditamos que, ao redigir o Adversus oppugnatores, João insere-se num amplo movimento que começa a ganhar consistência na segunda metade do século IV: o da conversão do mosteiro numa escola, ou seja, num ambiente propício às atividades de ensino-aprendizagem, o que coincide com o súbito aumento de crianças postas sob a responsabilidade dos monges, acontecimento cada vez mais comum à medida que avança a Antiguidade Tardia.

\section{Da escola greco-romana à escola monástica}

Em Roma, a escolarização, em todos os seus níveis, era um privilégio concedido aos meninos e rapazes da elite. Ainda que as meninas pudessem ser alfabetizadas e aprender rudimentos de literatura e matemática, seu destino era o casamento e a procriação, atividades para as quais não se exigia qualquer competência em gramática, aritmética ou retórica. Na medida em que a educação, na Antiguidade, era um serviço privado, dominado por uma legião de professores que atuava com bastante independência, visto não existir qualquer certificação para se exercer o magistério, os pobres também se encontravam excluídos das salas de aula. Quando muito, dependendo das posses da família, poderiam frequentar a escola de primeiras letras (BLOOMER, 2013, p. 453). Disso resulta que, quando nos referimos à escola greco-romana, estamos, na maioria das vezes, a tratar de uma realidade à qual somente os indivíduos do sexo masculino e pertencentes aos segmentos sociais mais abastados tinham acesso, com uma ou outra exceção. ${ }^{7}$ Mas, qual seria o propósito da paideia ou da humanitas, qual a sua principal finalidade? A formação escolar convencional, para além de conferir determinada identidade aos membros da elite, de reunir, nela mesma, um conjunto de códigos, valores e regras que permitiriam aos romanos de "boa família" se apresentarem como indivíduos de condição superior diante de uma massa anônima e por via de regra iletrada, era também algo indispensável àqueles que desejassem fazer carreira nos ramos civil e militar da administração pública, exigência que se torna cada vez maior a partir de fins do século III, tendo em vista o aumento e a especialização da burocracia imperial na sequência das reformas implementadas por Diocleciano e Constantino.

\footnotetext{
${ }^{7}$ Muito embora a escolarização greco-romana fosse um privilégio dos indivíduos do sexo masculino, temos conhecimento de algumas mulheres - poucas, por sinal - que se distinguiram por suas qualidades intelectuais, tendo atuado inclusive como professoras, a exemplo de Hipácia, filha de Theon, um dos integrantes do Mouseion de Alexandria. Ao que tudo indica, no entanto, trata-se de exceções que confirmam a regra. Para informações complementares sobre a formação, a carreira e o trágico fim de Hipácia, trucidada por um bando de cristãos, consultar Dzielska (2009).
} 
Em Roma, desde a República, a educação dos meninos era um assunto que dizia respeito ao pater familias, como vemos no caso de Cícero, que supervisionava pessoalmente os estudos do filho e do sobrinho, tendo enviado ambos à Grécia a fim de aprimorarem sua formação (BLOOMER, 2017, p. 167). A educação das meninas, por sua vez, ficava a cargo da mãe, que deveria ensiná-las a ser esposas dedicadas e donas de casa competentes, cabendo ao pai tão somente zelar pela subsistência das filhas e provê-las com o dote, fundamental para que pudessem contrair matrimônio (VUOLANTO, 2013, p. 582). No decorrer da época imperial, os pais continuaram a cumprir o papel de supervisores da educação dos filhos, o que significava tanto garantir que frequentassem a escola quanto introduzi-los na vida pública, acompanhando-os ao fórum, ao anfiteatro e ao teatro, por exemplo. Ao contrário do que poderíamos supor, em função da escassa quantidade de informações sobre a infância que chegou até nós, no Império Romano, a educação das crianças, ou melhor, dos meninos, era um assunto da maior relevância, tendo atraído a atenção não apenas dos pais, mas também de muitos outros agentes: sofistas, filósofos, autores teatrais e personalidades influentes, incluindo o princeps, que logo assumiu o papel de promotor dos estudos avançados de grego e latim mediante a instituição de cátedras para o ensino de ambas as disciplinas. ${ }^{8}$

Sob o Império Romano, a maioria daqueles com condições de, em algum momento, frequentar a escola recebia apenas uma instrução funcional, aprendendo a ler e a escrever, mas sem aprofundar-se na literatura clássica. Em geral, as crianças começavam a estudar por volta dos sete anos, ocasião em que meninos e meninas poderiam integrar a mesma classe. Nesse primeiro nível, além da escrita e da leitura, aprendia-se também a aritmética (BLOOMER, 2013, p. 451). Embora alfabetizados, é provável que muitos desses indivíduos, ao interromperem o processo de escolarização num estágio ainda precoce, terminassem por esquecer os conhecimentos adquiridos, não apenas em virtude do passar dos anos, mas também do tipo de ofício que viessem a exercer, uma vez que, no caso de artesãos ou agricultores, o domínio dos códigos da escrita e da leitura não seria decerto uma habilidade indispensável. Após cerca de quatro anos na escola de primeiras letras, os alunos com melhor condição financeira passavam à escola do grammaticus, na qual o letramento seria posto a serviço do aprendizado da literatura clássica. Quando os estudantes se mostravam mais seguros, o professor dava início a uma série de exercícios denominados progymnasmata, cujo objetivo era treiná-los na composição de breves

\footnotetext{
${ }^{8} \mathrm{O}$ primeiro imperador a estabelecer cátedras oficiais de retórica grega e latina foi Vespasiano, que concedeu uma subvenção anual de cem mil sestércios aos docentes de ambas as disciplinas, cujo local de atuação era a cidade de Roma. Na ocasião, Quintiliano foi o primeiro a ocupar a cátedra de latim. Mais tarde, Marco Aurélio institui uma cadeira para o ensino de grego e quatro para o de filosofia em Atenas (MARROU, 1990, p. 463).
} 
narrativas mediante o emprego das competências gramaticais já consolidadas. Após mais quatro anos, aos treze ou quatorze anos de idade, os alunos encontravam-se aptos a migrar para a escola dos rétores, a fim de cumprir a última etapa do seu percurso educacional. Na maioria das vezes, isso implicava uma transição abrupta de um mestre a outro - e mesmo de uma cidade a outra, caso a família dispusesse de recursos suficientes para enviar os filhos ao exterior -, mas, não raro, o estudante poderia cumprir uma fase preliminar de adaptação ao frequentar, ao mesmo tempo, as lições do rétor e as do gramático. Sob a orientação do rétor e dos seus auxiliares, os alunos aprofundavam seus conhecimentos nos textos gregos e latinos, liam e comentavam o trabalho dos autores clássicos e redigiam suas próprias composições. Ao término dessa etapa, que durava cerca de três anos, encontravam-se aptos a redigir, memorizar e declamar suas próprias composições. O próximo passo seria buscar uma colocação numa das carreiras do serviço imperial. No entanto, aqueles que o desejassem poderiam dar continuidade aos estudos, especializando-se em direito, filosofia ou medicina (WATTS, 2012, p. 469-470).

A escola greco-romana não possuía, a rigor, nenhum design específico, variando consideravelmente em forma e tamanho. Embora tenhamos notícia da existência de escolas com capacidade para atender cerca de 100 alunos, a maioria era constituída por empreendimentos modestos, funcionando na própria residência dos docentes ou mesmo ao ar livre. Evidências de salas de aula convencionais, contendo bancos, cadeiras para os professores e paredes empregadas como lousas são raras. O mais provável é que os alunos se sentassem no chão, reunidos em torno do mestre, que, por sua vez, ocupava uma posição mais elevada. Os professores costumavam manter uma biblioteca própria composta pelas principais obras literárias gregas e latinas, muito mais para consumo próprio do que para o atendimento aos estudantes, muitos dos quais, pertencendo à elite, dispunham de um acervo literário particular, patrimônio de família (BLOOMER, 2013, p. 453-454). Assim como ocorre nos dias de hoje, a transição do ambiente doméstico para o escolar equivalia ao ingresso do aluno em um novo mundo. Em se tratando dos níveis superiores, essa ruptura por vezes era ainda mais profunda, na medida em que os alunos poderiam ser enviados a estudar em grandes centros distantes da sua residência, a exemplo de Roma, Alexandria, Antioquia, Atenas ou Berito, apenas para citar os mais proeminentes. Embora as crianças da elite pudessem ser instruídas em casa por tutores contratados pelos pais ou mesmo por escravos que, por ventura, fossem letrados, a escola era considerada o local mais apropriado para a socialização das crianças e jovens, em detrimento da educação dispensada no lar. Caso a família dispusesse de recursos, o aluno poderia ser acompanhado à escola por um pedagogo, que o auxiliaria nas lições, e por um capsarius, um escravo encarregado de portar os cilindros com os rolos de papiro. 
Ambos, sem dúvida, atuariam como olhos e ouvidos dos pais, garantindo aos alunos, mesmo a distância, a continuidade da proteção paterna. Malgrado a sua novidade, a escola por vezes era considerada uma segunda família, pois os estudantes costumavam chamar seus professores de "pai" e seus colegas de "irmãos". Mais que isso, em alguns casos, os professores se tornavam protetores dos alunos, acolhendo-os e sustentandoos, em especial quando se tratava de estudantes provenientes de outras localidades e, portanto, longe de casa (WATTS, 2012, p. 472). Assim como o pai, os professores tinham autoridade suficiente para disciplinar os alunos, recorrendo inclusive à violência. Não por coincidência, o instrumento característico do professor era a ferula ou a virga, ou seja, a vara com a qual punia os estudantes relapsos, já que o emprego de castigos físicos era um componente estrutural do processo pedagógico, como nos permite concluir a sentença "philoponei me dares" ("trabalhe duro ou serás castigado"), uma das mais frequentes nos exercícios escolares. Na opinião de Agostinho, era preferível morrer do que retornar à escola, um local definitivamente associado a dor e sofrimento (BLOOMER, 2017, p. 170).

$\mathrm{O}$ advento do cristianismo não acarretou, de imediato, qualquer alteração significativa no sistema escolar greco-romano, pois até pelo menos o século $V$ não havia escolas cristãs propriamente ditas, ou seja, escolas que ao mesmo tempo proporcionassem uma formação cultural comum aos membros da elite e que ensinassem aos alunos os conhecimentos necessários à obtenção de uma boa colocação profissional. Desse modo, tanto os pagãos quanto os cristãos eram instruídos por meio dos grandes autores do passado, todos eles porta-vozes da cultura clássica, razão pela qual, ao lado da língua, eram transmitidas também as tradições, os costumes e os valores greco-latinos, incluindo as proezas dos deuses do paganismo, uma vez que o currículo da escola do grammaticus incluía, entre outras disciplinas, a mitologia (BLOOMER, 2013, p. 451). Isso equivale a dizer que, por séculos, os cristãos com condições de frequentar as escolas receberam uma instrução ancorada na paideia, ou seja, na cosmovisão greco-romana, ao passo que muitos docentes, a despeito de professarem o cristianismo, não deixaram de exercer o magistério de acordo com os mesmos protocolos adotados pelos seus colegas pagãos. Além disso, não faltam exemplos de cristãos que, educados na paideia, dela souberam se aproveitar muito bem, como João Crisóstomo, o mais competente orador cristão de língua grega da Antiguidade.

João Crisóstomo era filho de Secundo, um funcionário graduado do staff do magister militum per Orientem, cujo praetorium, na segunda metade do século IV, encontrava-se instalado em Antioquia (KELLY, 1995, p. 4-5). Embora Secundo fosse um funcionário civil de patente superior, possuindo rendimentos suficientes para proporcionar aos membros da sua casa uma vida confortável, sua família não seria capaz de assumir despesas 
vultosas. Por esse motivo, quando da morte precoce do marido, a mãe de João, Antusa, teve de recorrer ao próprio dote para garantir a educação do filho, que estudou retórica com Libânio e filosofia com Andragácio, dois dos melhores professores disponíveis em Antioquia. Tudo leva a crer que João estivesse sendo preparado para uma carreira na administração pública, o que o levaria a ocupar um dos sacra scrinia, ou seja, um dos escritórios da chancelaria comandados pelo magister officiorum, ou a atuar como redator de leis a serviço do quaestor sacri palatii, o que representaria um avanço profissional em comparação ao seu pai, pois, ao contrário do magister militum, o magister officiorum e o quaestor sacri palatii eram funcionários instalados na corte e, portanto, mantinham contato direto com o imperador (JONES, 1953, p. 172). Em que pese a excelente formação que recebeu, João Crisóstomo mostrava-se, contudo, cada vez mais atraído pela vida monástica, o que o levou, antes mesmo de conviver com os monges do Monte Sílpios, a ingressar no asketerion, ${ }^{9}$ um círculo de jovens antioquenos que, sob a liderança de Diodoro e Cartério, praticavam o ascetismo e se dedicavam ao estudo das Escrituras.

A trajetória de João Crisóstomo, de promissor candidato a um posto na chancelaria imperial a asceta da congregação de Antioquia, exprime, nas entrelinhas, não apenas o despertar de uma vocação religiosa, mas também um estranhamento entre dois estilos de vida, problema que afetava, em particular, os cristãos da elite, cujos filhos, embora submetidos a uma escolarização cujos conteúdos derivavam do patrimônio cultural greco-romano, ansiavam, por vezes, a uma formação mais condizente com a crença que professavam. O dilema moral vivido pelos cristãos educados na paideia não era decerto uma novidade na época tardia. Ocorre, no entanto, que o conflito entre o cristianismo e a cultura clássica se aprofunda nos séculos IV e V, num contexto de rápido avanço da cristianização, o que deu ensejo, por exemplo, à célebre lei de Juliano proibindo o exercício do magistério pelos professores cristãos, conforme reportado por Amiano Marcelino (XXV, 4, 20). Na concepção do imperador, os cristãos, por não crerem nos deuses do paganismo, não poderiam viver do ensino de disciplinas cujos conteúdos eram plenos de referências às divindades greco-romanas. Já do lado dos cristãos, a cristianização colocava os pais numa encruzilhada, pois, ao mesmo tempo que aspiravam a um futuro de sucesso para os filhos, o que somente seria garantido mediante uma formação competente em retórica, direito ou filosofia, tinham também o dever moral de os educar como cristãos

\footnotetext{
${ }^{9} \mathrm{O}$ asketerion não era uma instituição semelhante a um mosteiro, mas antes um círculo itinerante de membros que se reuniam para a prática do ascetismo e para o estudo das Escrituras. Os jovens que o frequentavam tratavam a si mesmos como irmãos e, no ato de adesão, eram inscritos num katalogos e faziam um juramento de renúncia ao casamento (LIEBESCHUETZ, 2011, p. 128; KELLY, 1995, p. 18).
} 
piedosos, protegendo-os ao máximo de qualquer influência pagã e, portanto, nociva ao seu crescimento espiritual (VUOLANTO, 2013, p. 581).

O resultado desse impasse foi a fundação de um sistema escolar propriamente cristão, cada vez menos dependente dos autores greco-latinos, processo que somente será concluído, no Ocidente, por volta dos séculos VI-VII, quando a educação se torna patrimônio dos monges e clérigos. No Oriente, por sua vez, o apego dos professores e estudantes aos clássicos atravessa todo o período bizantino, como comprova a vitalidade da "Universidade" de Constantinopla, um centro de ensino superior fundado, em 425, por Teodósio II, que até 1453 continua a formar quadros para a administração imperial com base no ensino da retórica, do direito e da filosofia (MARROU, 1990, p. 517-518). Porém, tanto a Oriente quanto a Ocidente constatamos, na Antiguidade Tardia, a emergência da escola monástica, destinada a desempenhar um importante papel na formação de religiosos e religiosas, é certo, mas igualmente de leigos, motivo pelo qual os mosteiros cedo se converteram numa alternativa à escola clássica, o que nos convida a analisar as instituições monásticas não apenas como instituições religiosas stricto sensu, mas também como instituições escolares, para além das suas atribuições econômicas, assunto que foge ao escopo deste artigo. Ao contrário do que poderíamos supor, a instituição das escolas monásticas não resultou tão somente da necessidade de oferecer letramento a uma massa ignara de camponeses que, a partir de meados do século III, começa cada vez mais a abraçar o ascetismo, primeiro na condição de anacoretas e, em seguida, como cenobitas, muito embora o mosteiro tenha cumprido com empenho a tarefa de alfabetizar os adultos que, nele, ingressavam. A bem da verdade, a exigência de que os mosteiros funcionassem como centros espirituais e como escolas encontra-se antes conectada a uma variável que, em decorrência do protagonismo assumido pelos ascetas adultos, por vezes nos escapa: a presença constante entre os monges, pelos mais variados motivos, de crianças e jovens em idade escolar, que deveriam receber tanto instrução religiosa quanto literária.

Entre os autores da Antiguidade Tardia, vemos mais ou menos difundida uma concepção segundo a qual as crianças eram criaturas humildes, libertas das paixões e assexuadas, o que as tornava semelhantes aos anjos, condição à qual os adultos somente poderiam aspirar mediante esforço e disciplina. Uma concepção como essa, que considerava as crianças seres castos e inocentes pela própria natureza, terminou por fazer delas candidatas preferenciais à vida monástica, havendo muitos defensores da convivência precoce das crianças com os monges como uma estratégia para melhor incutir nelas os preceitos cristãos. Importa reconhecer que nem sempre a presença de meninos e meninas nos mosteiros era aceita com naturalidade, seja porque as crianças, com suas brincadeiras 
e algazarras, perturbavam a rotina de estudo e meditação, ou mesmo por representarem uma constante ameaça à castidade dos monges. Embora a literatura monástica mencione com parcimônia a prática de relações sexuais no interior dos mosteiros, sabemos que os encontros amorosos ocorriam tanto entre monges adultos quanto entre estes e os meninos (LEYERLE, 2013, p. 559 et seq.). Seja como for, a tendência predominante entre os primeiros líderes cenobitas, responsáveis pela fixação de normas de convívio mútuo que adquiriam um alcance universal à medida que progredia o movimento monástico, era a de autorizar que crianças fossem criadas pelos monges, como expresso nas regras de Pacômio, Shenoute, Basílio e Bento de Núrsia.

O ingresso de uma criança no mosteiro poderia ocorrer por diversos motivos. Em primeiro lugar, havia aquelas que, acompanhadas pelos pais ou por algum outro familiar, eram levadas a visitar, por curtos períodos de tempo, os monges, o que lhes permitia travar contato com o ambiente monástico. O pretexto para uma visita inicial ao mosteiro era quase sempre a busca pela intercessão dos ascetas diante de algum distúrbio de ordem física ou espiritual. Em se tratando de uma estadia mais longa, as crianças poderiam ter sido levadas ao mosteiro pelo pai, pela mãe ou por algum outro parente que houvesse assumido os votos religiosos ou simplesmente teriam sido recolhidas por serem órfãs. Com certa frequência, crianças eram entregues aos cuidados dos monges devido a algum pacto ou negociação efetuado pelos pais, como revelam contratos coptas atestando a doação legal de crianças ao mosteiro, que deveria zelar pela sua subsistência (GIORDA, 2017, p. 233). Além disso, tudo indica que os mosteiros constituíram, desde cedo, uma alternativa para o aborto, o infanticídio e a exposição, práticas correntes na Antiguidade e que prosseguiram por toda a Idade Média, a despeito do discurso cristão, que as condenava com veemência (LEYERLE, 2013, p. 565). Em alguns casos, a criança era propriedade de um dos membros do convento e se encontrava ali para trabalhar. Ao se tornar adulta, não era libertada, mas permanecia unida aos monges por algum vínculo de dependência. Muito embora todas as crianças residentes no mosteiro devessem, em tese, executar serviços manuais, havia aquelas que eram doadas pelos pais com o propósito de servirem como mão de obra adicional e não para seguirem a carreira religiosa. Havia, além disso, os oblatos, ou seja, as crianças confiadas aos monges para serem educadas nos preceitos cristãos, encontrando-se livres para partir após determinada idade mediante o pagamento de uma taxa, o demosion (GIORDA, 2017, p. 241). Uma última modalidade de ingresso no mosteiro, muitas vezes desconsiderada, era a adesão voluntária, quando a própria criança rompia com a família para dedicar-se à vida ascética, o que nos recorda o quanto as crianças nem sempre eram submissas à vontade dos adultos, como revela a biografia de São Sabas, que, por volta dos oito anos de idade, decidiu, por si mesmo, 
internar-se numa instituição monástica. ${ }^{10}$ Muito embora alguns autores cristãos não se mostrassem favoráveis à ideia de que indivíduos muito jovens pudessem optar pelo noviciado, a exemplo de Basílio, para quem um rapaz ou uma moça somente poderiam ter discernimento sobre os rumos da sua vida aos dezesseis ou dezessete anos, não era incomum, na Antiguidade Tardia, que crianças em idade precoce fossem aceitas como noviças, princípio sancionado pelo concílio de Trulo, reunido em Constantinopla, em 692, que, no seu $40^{\circ}$ cânone, autorizava as crianças a optarem pelo monacato aos dez anos de idade (CASEAU, 2017, p. 225).

Considerando as diversas categorias de crianças postas sob os cuidados dos monges, é possível concluir que nem todas necessariamente assumiriam os votos monásticos, podendo, em alguma medida, desligar-se do mosteiro ao se tornarem adultas, ainda que, no caso das servas, tal alternativa fosse mais difícil, na medida em que elas eram tidas como propriedade da instituição, integrando assim o patrimônio monástico. A despeito da razão que as levaram ao mosteiro, as crianças que ali se encontravam deveriam receber não apenas uma formação religiosa, mas também literária, razão pela qual, desde o seu surgimento, os mosteiros funcionaram tanto como centros espirituais, ensinando aos servos, noviços e oblatos todo o repertório de práticas ascéticas e contemplativas, quanto como escolas, nas quais eram adotados recursos pedagógicos não muito distintos daqueles da escola greco-romana (GIORDA, 2017, p. 240). De fato, os autores cristãos da Antiguidade Tardia que se dedicaram a refletir sobre o cotidiano das instituições monásticas e sobre o serviço por elas prestado são unânimes em reiterar a necessidade de instruir, ao menos nas primeiras letras, as crianças, os jovens e mesmo os adultos analfabetos. Pacômio, por exemplo, insistia que todos os monges deveriam aprender a ler, começando pelas sílabas e depois prosseguindo com os substantivos e verbos. Para tanto, reservava, em sua Regra, três horas diárias ao estudo. Já Basílio determinava que as crianças, desde os seus primeiros anos, deveriam estudar sob a orientação de um dos anciãos do mosteiro. A Regra, de Basílio, recomendava, inclusive, que, em lugar do repertório mitológico da escola pagã, fossem empregados, como recursos pedagógicos, nomes de personagens bíblicas, versículos do Livro dos Provérbios e histórias de santos (MARROU, 1990, p. 503; LEYERLE, 2013, p. 571).

\footnotetext{
${ }^{10}$ São Sabas, cuja vida conhecemos por intermédio de uma hagiografia escrita por Cirilo de Citópolis, foi um asceta oriundo de Cesareia da Capadócia nascido em 439. Ainda criança, São Sabas foi deixado aos cuidados de um tio, pois seu pai, um oficial militar, foi obrigado a se transferir para o Egito, tendo sido, na ocasião, acompanhado pela esposa. Devido a desavenças com o tio, São Sabas busca refúgio na casa de outro tio. Quando ambos entram em litígio pela herança do sobrinho, este, então com apenas oito anos de idade, decide recolher-se a um mosteiro dirigido por Flaviano II, o patriarca de Antioquia. Aos dezessete anos, recebe a tonsura monástica e, aos dezoito, deixa a comunidade, dirigindo-se a Jerusalém, onde passa a residir no convento de Teoctisto (CASEAU, 2017, p. 223).
} 
Evidências arqueológicas provenientes do Alto Egito têm, por sua vez, revelado a existência, nos mosteiros da região, de aposentos utilizados como escritórios e salas de aula e de uma grande quantidade de exercícios escolares, alguns deles redigidos em copta (CRIBIORE, 2001, p. 24). Desse modo, desde o século IV vemos florescer, tanto a Oriente quanto a Ocidente, a escola monástica, orientada basicamente para a formação religiosa e calcada no conhecimento das Escrituras, que deveriam ser aprendidas de cor pelos monges. Mas, para tanto, era necessário lê-las. Não que a escola monástica tenha prontamente substituído a escola dos gramáticos e dos rétores, uma vez que ambas possuíam missões bastantes distintas. Enquanto a primeira priorizava a educação espiritual, a segunda cumpria uma função, por assim dizer, profissional, ao formar quadros para a administração imperial, além de ser, como vimos, um emblema identitário para os membros da elite. Ocorre, no entanto, que, num contexto marcado pela experiência do ascetismo e pelo desejo de renúncia ao mundo, como o da Antiguidade Tardia, as exigências do saeculum e os preceitos evangélicos mostravam-se não raro incompatíveis, o que conduziu, em algumas circunstâncias, a uma radicalização do discurso eclesiástico, no sentido de rejeitar tudo aquilo que estivesse associado ao modus vivendi pagão ou judaico, incluindo a formação educacional das crianças e jovens. Nesse amplo debate envolvendo as relações entre o cristianismo e a cultura clássica, um autor de destaque é, sem dúvida, João Crisóstomo, que, no Adversus oppugnatores, ao exaltar a vida monástica, busca construir uma alternativa à paideia ao propor que a instrução das crianças - vale dizer, dos meninos - deveria ser confiada aos monges, os únicos capazes de assumir com competência essa tarefa.

\section{Um asceta e sua pedagogia monástica}

Como mencionamos, a inclinação de João Crisóstomo pela vida ascética remontava aos seus tempos de juventude, quando, na companhia de outros colegas da mesma idade, fez parte do asketerion, tendo inclusive pretendido, em certa ocasião, coabitar com um amigo, Basílio, numa célula monástica urbana, projeto que não levou adiante devido aos insistentes apelos de sua mãe, que temia morrer no abandono (KELLY, 1995, p. 16). Após a morte de Antusa, João encontrava-se enfim livre para se dedicar ao ascetismo, dirigindo-se então ao Monte Sílpios, situado a leste de Antioquia, onde diversos monges haviam se instalado na condição de anacoretas e de cenobitas. João passa quatro anos numa comunidade de ascetas, repartindo a tenda com um ancião conhecido como "o Sírio", responsável por supervisionar seu treinamento. Concluída essa fase inicial, se interna numa caverna por mais dois anos, onde passa a maior parte do tempo em vigília, 
aprendendo as Escrituras, sem se sentar ou deitar. Os rigores aos quais se submeteu foram tão intensos que terminaram por comprometer sua saúde, deixando-o com sequelas gástricas que o atormentaram pelo resto da vida (LIEBESCHUETZ, 2011, p. 130). Após seis anos em companhia dos monges, por volta de 378 , João regressa a Antioquia, quando então é ordenado diácono por Melécio, seu mentor espiritual. A experiência adquirida nos anos de juventude, tanto no asketerion quanto na passagem pelo Monte Sílpios, marcaram profundamente sua personalidade, motivo pelo qual, mesmo abraçando a carreira sacerdotal na condição de diácono, o que lhe abriria as portas do presbiterado e, mais tarde, do episcopado, João nunca deixou de se comportar como um asceta e de fazer o elogio da vida monástica, pois, segundo ele, os monges eram a prefiguração dos anjos, ou seja, a condição mais perfeita à qual um ser humano poderia aspirar sobre a Terra, além de serem portadores de poderes miraculosos (LAl, 2011, p. 20). No entanto, seu entusiasmo pelo monacato não era, em absoluto, compartilhado pelos pais da elite de Antioquia, que reagiam muito mal à possibilidade de verem os filhos seguir a vida monástica, pois desejavam para eles um posto nas fileiras da administração imperial, assim como Antusa havia sonhado outrora para João.

Ao que tudo indica, no norte da Síria, o conflito entre as famílias cristãs e os monges era particularmente grave nas últimas décadas do século IV. A região já era, desde pelo menos o século III, conhecida pelo fervor dos seus ascetas, como comprovam os "Filhos e Filhas do Pacto" (i. é, do batismo), uma comunidade de leigos batizados que, embora vivendo em ambiente urbano, observavam um estilo de vida peculiar, renunciando ao casamento e à procriação e preservando a virgindade, valores que, mais tarde, seriam incorporados ao movimento monástico (BAKER, 1968, p. 347). No passado, acreditava-se que o monacato sírio tivesse resultado de influxos provenientes do Egito, mas hoje a maioria dos autores descarta essa hipótese, defendendo antes a tese de um surgimento independente. De início, as personagens mais importantes do monacato sírio são os anacoretas, a exemplo de Juliano Sabas e Abraão Qidunaya (ou seja, de Beyt Qiduna, uma aldeia próxima a Edessa), que viviam ao relento, alimentando-se de frutos e raízes e experimentando mortificações as mais bizarras. De certa maneira, o movimento monástico, na Síria, é dominado por essas figuras, capazes de suportar, sobre o pescoço, o jugo de pedras e grilhões e de permanecer, por anos a fio, de pé sobre uma coluna, como vemos no caso de Simeão, o Estilita, o campeão dos anacoretas sírios (BROCK, 1973, p. 9-13). No entanto, o eremitismo não era a única modalidade de exercício do monacato a prevalecer no norte da Síria, que, desde meados do século IV, já contava, tanto na planície, na região do deserto, quanto nas colinas que faziam parte do Maciço do Calcário, localizado entre o território de Antioquia e o de Apameia, com comunidades 
monásticas que, pouco a pouco, evoluem da condição de um conglomerado de cabanas para edificações em pedra, o que assinala, segundo Hull (2016, p. 106), um grau superior de institucionalização.

No norte da Síria, o mais antigo mosteiro do qual temos notícia data de aproximadamente 330, tendo sido fundado por Astério, discípulo de Juliano Sabas, nas cercanias de Gindaro, uma das cidades-satélites de Antioquia, como narra Teodoreto de Ciro (2, 9), em sua História dos monges da Síria, também conhecida como História Religiosa. Cerca de vinte anos depois, por volta de 350, na planície de Dana, entre Antioquia e Bereia, certo Amiano funda o mosteiro de Teleda, o mais famoso da região, no qual veio a ensinar Eusébio, um célebre anacoreta, que termina por suceder a Amiano como superior monástico (Theod., Hist. Rel., 4, 2, 4). Teodoreto (Hist. Rel., 4, 13) menciona que, ao redor de Teleda, logo surgiram outras instituições similares, uma das quais veio a abrigar Simeão, o Estilita. Na década de 380, temos notícia de dois outros mosteiros, situados no Monte Amano, a oeste de Antioquia, cujo fundador teria sido Simeão, o Velho, ao regressar de uma peregrinação ao Sinai (Theod., Hist. Rel., 6-13). Ainda que as informações sobre as instituições monásticas do norte da Síria contidas na História Religiosa não sejam abundantes, em virtude da própria natureza da obra, um conjunto de biografias cujo propósito era exaltar a vida e os feitos milagrosos dos anacoretas e eremitas, não resta dúvida que, a partir da segunda metade do século IV, vemos multiplicarem-se as comunidades cenobíticas, o que coincide com o avanço do cristianismo na khora síria. Essa conclusão é corroborada por João Crisóstomo, que, em suas homilias, faz diversas referências aos ascetas que habitavam o Monte Sílpios e com os quais mantinha, desde os tempos de juventude, contatos estreitos. ${ }^{11}$ Do ponto de vista arquitetônico, os mosteiros do norte da Síria exibiam duas peculiaridades notáveis quando comparados aos do Sul, muito mais suscetíveis às influências do monacato egípcio: a ausência de muralhas de proteção e a sua instalação em sítios vizinhos às aldeias, o que tornava o mosteiro bastante acessível à comunidade ao redor (PRICE, 1985 , p. xix-xx). Segundo estimativas de Hull $(2016$, p. 95), cerca de $50 \%$ dos mosteiros erguidos no Maciço do Calcário situavam-se num raio de $1 \mathrm{~km}$ de distância do povoado mais próximo, ao passo que $80 \%$ situavam-se num raio de $2 \mathrm{~km}$. Disso resulta que, em Antioquia e arredores, os mosteiros não eram erguidos em locais ocultos e inacessíveis,

\footnotetext{
11 À época de João Crisóstomo, alguns dos ascetas radicados nos arredores de Antioquia já viviam em mosteiros (coenobia), embora o autor, em Adversus oppugnatores, não forneça detalhes acerca da organização dessas instituições, pois seu principal objetivo era enfatizar o sentido filosófico do monacato, descrevendo-o como uma alternativa de vida (LIEBESCHUETZ, 2011, p. 108-109). Para uma seleção de passagens das homilias de João Crisóstomo nas quais o pregador se refere aos mosteiros do Monte Sílpios, consultar o capítulo XI ("Les monastères 'antiochiens' d'après Chrysostome") da obra magna de Festugière (1959, p. 329-346)
} 
mas se destacavam na paisagem, o que decerto favorecia o contato entre os monges e a população e, por conseguinte, o proselitismo monástico.

As tradições seculares do ascetismo sírio combinadas com a fundação de comunidades monásticas, que, de certa forma, conferiam aos noviços maior conforto e segurança em comparação às rudes condições vividas pelos anacoretas, isso sem mencionar todo um discurso em favor da renúncia ao mundo propagado pelas lideranças eclesiásticas, foram, muito provavelmente, os principais fatores responsáveis por aquilo que Leroux (1975, p. 127) qualifica como "explosão da vida ascética" a partir de meados do século IV, num movimento que se prolonga pelos dois séculos seguintes e cujos desdobramentos podem ser acompanhados por meio do registro arqueológico, tendo sido atestada a existência de pelo menos 135 mosteiros no Maciço do Calcário entre os séculos V e VI (HULL, 2016, p. 91). Ainda que talvez seja um exagero supor, como faz Festugière (1959, p. 192), a ocorrência, na segunda metade do século IV, de uma "epidemia" de vocações entre os jovens da elite antioquena, o que teria desencadeado a ira dos pais contra os monges, não resta dúvida que o problema estava longe de ser irrelevante, uma vez que João Crisóstomo se ocupa do assunto, não por meio de um opúsculo, mas de um extenso tratado repartido em três livros.

Em Adversus oppugnatores, João Crisóstomo inventa um interlocutor ao qual se dirige a fim de defender o convívio precoce entre as crianças e jovens e os monges, o que seria algo absolutamente benéfico para a formação educacional daqueles. Ao mesmo tempo, condena com firmeza os abusos cometidos contra os ascetas por cristãos e pagãos, insatisfeitos com a atração exercida pelo monacato sobre seus filhos. O problema é a ele reportado pelo seu interlocutor imaginário nos seguintes termos:

Como se um espírito maligno houvesse penetrado na alma de todos, esse assunto encontra-se nos lábios de todos. Vá à ágora, vá ao consultório dos médicos, vá a qualquer lugar na cidade onde aqueles que apreciam não fazer nada se reúnem regularmente e você verá todos rindo. O assunto de suas risadas e zombarias são essas histórias de ataques contra os homens santos. Assim como apraz aos guerreiros que venceram muitas batalhas e ergueram monumentos falar das suas façanhas, assim essas pessoas se regozijam com os seus feitos rudes. Você ouvirá um dizendo: 'eu fui o primeiro a deitar as mãos em tal ou tal monge, e eu o golpeei'. Outro diz: 'eu encontrei sua cabana antes de qualquer outro'. 'Mas eu provoquei o juiz mais do que qualquer outro', diz um terceiro. Outro ainda se jacta da prisão e dos seus horrores, e reclama elogios por ter arrastado esses homens santos através da ágora. E assim prosseguem. E essas coisas ocorrem em reuniões de cristãos! E os pagãos riem ao mesmo tempo dos escarnecedores e dos escarnecidos [....]. Esse conflito é pior do que uma guerra civil, não apenas porque é movida contra pessoas santas que nada têm feito de errado, mas também porque é dirigida contra aqueles que não sabem como fazer mal a ninguém e que estão preparadas apenas para sofrer (Adv. oppug., I, 2). 
Segundo o relato, os cristãos de Antioquia estariam envolvidos num movimento coletivo de repressão aos monges com o propósito de impedir que estes se aproximassem de seus filhos. O assunto, ao que parece, era voz corrente na cidade, sendo motivo frequente de comentário na ruas e praças, o que criava uma espécie de identidade entre os pais, reunidos para narrar suas ações e justificá-las para si mesmos e para os demais, o que decerto serviria de estímulo a que novos abusos fossem cometidos contra os monges. João Crisóstomo, nessa passagem, nos permite também supor a existência de um intercâmbio regular entre os espaços urbano e monástico, pois um dos pais afirma ter localizado o asceta em sua cabana, ao passo que outro alega ter arrastado alguns monges através da ágora, talvez com o intuito de expulsá-los da cidade ou entregá-los às autoridades. $\mathrm{O}$ choque entre os pais e os monges era, pois, um acontecimento que à época movimentava Antioquia, causando indignação ao pregador, para quem tratava-se do emprego de violência gratuita contra indivíduos completamente inofensivos, o que, todavia, não correspondia inteiramente à verdade, pois sabemos o quanto os monges, na Antiguidade Tardia, eram capazes de executar ações violentas, por vezes agindo como uma turba enfurecida. ${ }^{12}$ Embora, nesse caso específico, seja improvável que os monges representassem qualquer tipo de ameaça física aos citadinos, seu comportamento, no fim das contas, não seria menos danoso, pois buscavam aliciar crianças e jovens para a vida monástica sem a permissão dos pais, que, por sua vez, julgavam isso uma afronta à sua patrio postestas e uma tentativa de interferência indevida na unidade familiar, da qual eram os legítimos defensores.

O destino dos filhos seduzidos pelos monges seria causa de profunda consternação para os pais, que não cessariam de se lamentar pela perda sofrida, como nos informa João ao reproduzir as queixas de um deles:

E o que é pior, após persuadi-lo [o filho] a fazer isso [deixar a casa paterna], eles [os monges] fingem saber o que é o melhor para ele. Casas e campos se tornam vazios. Agricultores e escravos domésticos se enchem de pesar e desgraça. Meus inimigos se comprazem com o meu infortúnio, meus amigos se ocultam com vergonha. Eu não tenho nenhum pensamento senão incendiar tudo, casas, campos, cabeças de gado e rebanhos de ovelhas. Pois que bem são essas coisas para mim agora, quando aquele que deveria fazer uso delas não está aqui, mas foi levado cativo e escravizado por bárbaros selvagens numa servidão mais amarga do que a morte? Eu vesti as pessoas da minha casa com trajes negros, espalhei cinzas em suas cabeças, organizei um coro de mulheres e as ordenei que se golpeassem com mais força do que se o houvessem encontrado morto. Agora, a luz do dia me perturba bastante e seus raios são insuportáveis, sempre que eu evoco em minha mente a imagem desta miserável criança, sempre que eu a vejo

12 Informações mais detalhadas quanto à predisposição dos monges para agir com violência, em particular contra os templos pagãos, podem ser encontradas em Silva (2014). 
vestida mais miseravelmente do que o mais vil dos agricultores e enviada para executar os trabalhos mais desonrosos (Adv. oppug., II, 2).

A decisão dos filhos em dar ouvidos aos monges era encarada, pelos pais, como uma autêntica desgraça, similar à morte, pois, em ambos os casos, se veriam privados dos seus eventuais herdeiros, não tendo assim a quem legar todo o patrimônio que construíram ao longo da vida: casas, propriedades agrícolas, escravos, rebanhos. Mais que isso, os pais se veriam numa posição desconfortável perante os vizinhos, tornandose motivo de escárnio para os inimigos e de vergonha para os amigos, o que nos revela o quanto o problema afetava não apenas a rotina doméstica, mas colocava em risco a posição da família na comunidade, cujo prestígio seria abalado pela perda do herdeiro e, no limite, pela extinção da própria linhagem, caso se tratasse de um único filho. No cerne da polêmica, encontra-se a perda do carisma familiar, na medida em que a opção da criança ou do jovem pelo monacato, um estilo de vida rústico e marcado pelo mais completo despojamento, assinalava uma degradação social, cujos sinais mais visíveis eram os andrajos com os quais os monges se vestiam e a obrigatoriedade de o menino realizar serviços manuais, realidade comum nos mosteiros, como vimos, mas considerada ultrajante em se tratando de um membro da elite. Por esse motivo é que João Crisóstomo insiste, em seu tratado, nos benefícios da vida monástica e no desprezo da riqueza pelos monges, que, nesse pormenor, se igualariam aos filósofos pagãos ou mesmo os superariam, argumento que não deve nos causar estranheza, tendo em vista o fato de que, para os Padres da Igreja, o cristianismo era mais do que um simples culto, ele era uma filosofia, ou seja, um modo de viver, ou antes, a verdadeira filosofia (RUBENSON, 2008, p. 640). Nesse sentido, o monge, assim como o filósofo, era desprovido de paixões e desapegado dos bens materiais, o que o habilitaria a suportar as mais duras privações com resignação e mesmo com alegria (Adv. oppug., II, 4-5).

Embora vivendo em condição de pobreza, o rapaz não deveria ser, em absoluto, motivo de vergonha para os pais, mas antes, de orgulho, como pondera João Crisóstomo, dirigindo-se ao pai que sofre:

Se você quiser, eu o persuadirei a descer das montanhas e ir até a ágora, e você verá a cidade inteira se voltar e apontar para ele maravilhada e com admiração, como se algum anjo celeste estivesse ao lado dele. Você pensa que glória seja algo diferente disso? Devido àquelas roupas gastas e imprestáveis ele será mais nobre, não somente em comparação àqueles que servem ao rei, mas também em comparação ao próprio rei, que porta sua coroa. Se ele estivesse vestido de ouro, ou mesmo de púrpura, com a coroa do rei na cabeça, deitado sobre camas de seda, sendo conduzido por mulas e tendo guarda-costas vestidos de ouro, ele não maravilharia ninguém mais do que faz agora, estando sujo e sem 
tomar banho, usando um traje humilde, não trazendo nenhum seguidor com ele e encontrando-se descalço (Adv. oppug., II, 6).

Ao se apresentar perante a cidade sujo, coberto de farrapos e descalço, o monge não causaria repulsa àqueles que o vissem, mas admiração, pois sua aparência despojada e carente dos adereços usados pelos ricos e poderosos seria um sinal inequívoco da sua condição superior. Na sua pobreza, o monge se mostraria liberto das amarras que o prendiam a este mundo, marcado pelo excessivo apego aos bens materiais, uma das principais causas da infelicidade humana. Além disso, os ascetas eram celebrados como theioi andrès, ou seja, homens divinos capazes de proezas miraculosas, e como prefigurações terrestres dos anjos, vivendo assim uma existência celestial sobre a Terra, de maneira que sua visita à cidade equivalia a uma epifania, a uma manifestação tangível do sagrado, e como tal deveriam ser reverenciados por todos. Devemos observar, no entanto, que a conversão dos monges em seres celestiais não era um processo inato, mas antes o resultado de todo um conjunto de práticas disciplinares dedicadas ao controle e ao regramento do corpo ancoradas numa cadeia de interditos e de renúncias cujo fim último era produzir a elevação espiritual do asceta. Ao lado dessa disciplina corporal, como vimos, havia também a necessidade de prover os monges com conhecimentos literários que lhes permitissem ler e aprender as Escrituras, não sendo recomendável, contudo, apartar a instrução da ascese monástica, pois ambas se completavam. Ao adquirir domínio sobre a leitura e a escrita, o monge seria capaz de outras tantas proezas que desafiavam os limites da capacidade humana, como aprender de cor a Bíblia ou passar dias e dias lendo em pé, o que fazia do ato de estudar mais uma oportunidade para o exercício do ascetismo. Essa formação monástica, envolvendo corpo e mente, é aquela que João Crisóstomo defende como a mais adequada para as crianças e jovens cristãos, cuja salvação era de responsabilidade dos pais. Um preceito divino da maior relevância, segundo o pregador, era o cuidado com a educação dos filhos, motivo pelo qual um dos pecados mais graves que os pais poderiam cometer seria afastar das crianças aqueles que desejassem o bem-estar delas, a exemplo dos monges. Além disso, o descuido com a elevação espiritual dos filhos poderia conduzi-los à possessão demoníaca e à morte precoce, ou seja, poderia acarretar danos irreversíveis, incluindo a danação eterna, o que, na opinião de João Crisóstomo (Adv. oppug., III, 3-4), seria mais grave do que o infanticídio. Do ponto de vista da doutrina cristã, tudo aquilo que os pais julgavam ser conveniente para bem criar os filhos era, no fundo, obsoleto, a começar pela educação greco-romana, como esclarece João Crisóstomo: 
Eu desejaria que a falta de conselhos úteis aos filhos fosse a única calamidade, pois isso não seria tão ruim. Mas, hoje, vocês os empurram na direção contrária. Quando os pais obrigam os filhos a estudar retórica, tudo o que dizem são palavras como estas: 'certo homem, de condição social inferior, nascido de pais humildes, após obter a perícia que advém da retórica, obteve as mais altas posições, acumulou grande riqueza, casou com uma rica mulher, construiu uma casa esplêndida, e é temido e respeitado por todos'. E outro diz: 'certo homem, após aprender latim, se tornou ilustre no serviço imperial e ele cuida de todos os assuntos internos'. E outro homem cita um terceiro exemplo. E eles falam daqueles que se tornaram ilustres na terra, mas nenhum deles menciona aqueles no céu. E se alguém tentasse mencionar isso, ele seria posto de lado como um desordeiro. Por essa razão, sempre que vocês cantam canções para seus filhos, não Ihes ensinam outra coisa senão o que se encontra na raiz de todos os males, inculcam neles os dois mais tirânicos desejos, isto é, o amor pelo dinheiro e - o que é mais abjeto - o amor pela glória vã e vazia. Ambas, sozinhas, são capazes de subverter todas as coisas, mas, quando ocorrem juntas e atacam a tenra alma da juventude, como rios caudalosos correndo juntos, elas destroem todas as suas virtudes, arrastando consigo tantos espinhos, tanta areia, tantos detritos que tornam a alma estéril e incapaz de produzir algo de bom (Adv. oppug. III, 5-6).

Mais adiante, João volta novamente a criticar o sistema escolar greco-romano, da maneira como se segue:

Quando a alma é disciplinada, nenhum dano advirá da falta de conhecimento em retórica, mas quando a alma é corrupta, isso resultará no maior dos prejuízos, mesmo se a língua é muito hábil. Na verdade, o dano será maior quanto mais o menino dominar a retórica, pois quando a vileza obtém experiência em falar, ela acarreta, de longe, ações piores do que a ignorância. [...]. A busca pela retórica requer um bom comportamento, mas um bom comportamento não requer a assistência da retórica. É possível viver uma vida de autocontrole sem uma educação literária, mas ninguém poderia adquirir habilidade oratória sem bom comportamento, já que todo o seu tempo seria consumido em vileza e imoralidade. Por isso, seu temor de fracasso [dos filhos] é muito mais apropriado no caso da educação retórica, pois fracassos nesse domínio são muito mais frequentes [...]. Que disposição salutar viria de um conhecimento das letras quando somos feridos por um golpe mortal? Tais opiniões são sustentadas não apenas por nós, que rimos da sabedoria pagã e a consideramos tolice, mas também pelos filósofos pagãos. É por isso que muitos deles tinham pouco interesse em educação. Alguns, inclusive, a desprezaram por completo, e passaram a vida inteira no ramo da filosofia dedicado ao comportamento. E, mesmo assim, viveram uma vida brilhante e se tornaram famosos [...]. Pois a retórica não é apropriada para filósofos ou para homens adultos, ela é apenas uma exibição dos jovens ( $A d v$. oppug. III, 11).

Em ambas as passagens, João Crisóstomo cuida de desestimular os pais a enviarem os filhos à escola do gramático ou do rétor, em primeiro lugar, pelo fato de que a instrução em retórica, ao garantir uma boa posição profissional ao aluno, o tornaria propenso ao luxo, à ostentação e à vanglória, um tema que mais tarde, na condição de presbítero, tratará com frequência em suas homilias. A formação em retórica seria, por si mesma, danosa à formação moral do aluno, que por ela seria corrompido, antes que educado. Em segundo lugar, o autor se empenha em valorizar a educação monástica, baseada no autocontrole 
(sophrosyne), uma das principais virtudes dos filósofos e, por extensão, dos monges, em detrimento da retórica, pois uma criança que não aprendesse a refrear seus impulsos e paixões não poderia fazer bom uso da palavra. Mais que isso, as regras para se viver uma vida virtuosa não derivariam, em absoluto, da instrução formal, pois filósofos célebres, a exemplo de Crates, Diógenes e Sócrates, dela teriam prescindido. Já os primeiros cristãos, embora iletrados, possuíam um domínio da palavra superior ao de qualquer orador pagão (Adv. oppug., III, 12). Quando se trata da formação educacional das crianças, a ênfase de João Crisóstomo recai, pois, no aperfeiçoamento moral, embora sem desprezar por completo o aprendizado das letras, que poderia ser dispensado pelos monges. Mas não se trata apenas de realçar as vantagens da educação monástica, já que o autor se desdobra em argumentos com o propósito de alertar os pais sobre os obstáculos que seus filhos teriam de enfrentar caso decidissem frequentar a escola greco-romana:

\begin{abstract}
Entre os monges, apenas alguns têm sido malsucedidos, enquanto que, nos estudos retóricos, apenas poucos têm obtido sucesso. E essa não é a única razão, mas há outras para temer a retórica. A falta de habilidade do menino, a ignorância dos professores, a negligência dos pedagogos, o desejo de ócio por parte dos pais, a incapacidade de pagar taxas e salários, a diferença de temperamento entre as pessoas, a maldade, inveja e má vontade dos companheiros de classe, e muitas outras coisas irão afastá-lo da sua meta. E isso não é tudo, pois mesmo quando a meta for alcançada, haverá outros obstáculos. Pois, quando ele tiver ultrapassado tudo e atingido o cume da educação, se ele não tiver sido impedido por alguns desses obstáculos, outras armadilhas estão ainda a sua espera. $\mathrm{O}$ capricho dos governantes, a inveja dos colegas de trabalho, a dificuldade dos tempos, a falta de amigos e a pobreza quase sempre frustrarão seu sucesso. Mas as coisas não sucedem dessa maneira entre os monges. Entre eles, apenas uma coisa é necessária - um desejo nobre e bom. Se isto estiver presente, nada poderá impedi-lo de atingir o ápice da virtude (Adv. oppug., III, 13).
\end{abstract}

Mais uma vez, João Crisóstomo cuida de desencorajar os pais a proporcionarem uma instrução convencional aos filhos, que, na sua passagem pela escola, se deparariam com inúmeros inconvenientes capazes de fazê-los desistir: falta de aptidão para os estudos, despreparo dos professores, gastos excessivos, ambiente hostil entre os colegas de classe. E mesmo que o aluno viesse a concluir sua formação, o exercício profissional também seria cercado de obstáculos, sem qualquer garantia de sucesso ou enriquecimento, o que contrastava de modo evidente com a carreira monástica, na qual a possibilidade de realização pessoal era muito maior. Por esse motivo, a fim de que o menino pudesse desfrutar de uma infância feliz e se tornar um adulto realizado, João Crisóstomo advoga que a criança, a partir dos dez anos, fosse entregue aos cuidados dos monges, pois, nessa idade, o indivíduo já seria responsável por seus pecados (Adv. oppug., III, 17). O tempo de permanência no mosteiro, no entanto, deveria ser aquele necessário para forjar o 
caráter da criança, podendo estender-se por uma ou duas décadas. Ao término desse período ele poderia retornar ao convívio da família e dos amigos, já tendo atingido a maturidade (Adv. oppug., III, 18). A "nova pedagogia", por assim dizer, formulada por João Crisóstomo não se fundamentava apenas na negação da escola greco-romana, mas incluía também a rejeição a tudo o que dissesse respeito à pólis, um ambiente repleto de vícios e imperfeições, a exemplo da fornicação com meninos, muitas vezes consentida pelos pais, prática duramente criticada no tratado (Adv. oppug., III, 8). Segundo o autor, em seu tempo, a cidade se encontraria corrompida, o que teria forçado aqueles que aspiravam a uma vida virtuosa (i. é, os monges) a buscar refúgio no deserto, para onde deveriam ser enviados os meninos (Adv. oppug., l, 7). Desse modo, a proposta educacional de João implicava um deslocamento espacial, uma vez que a criança deixaria a casa dos pais e, por conseguinte, a própria cidade para viver em outro local e em outra koinonia submetida a outras regras:

Nos mosteiros, mesmo se uma tempestade [i. é, as atribulações] se formasse, as pessoas que ali residem viveriam em tranquilidade, no porto, em grande segurança, observando o naufrágio dos outros, como se estivessem no céu. Pois elas escolheram um modo de vida que se adéqua ao céu e alcançaram um estágio de modo algum inferior ao dos anjos. Assim como entre os anjos não há desigualdade, nem alguns desfrutam da prosperidade enquanto outros experimentam a miséria, mas todos compartilham a mesma paz, a mesma alegria, a mesma glória, no mosteiro sucede o mesmo [...]. Todas as coisas são tidas em comum: comida, abrigo, roupas. E por que isso seria surpreendente, se todos compartilham a mesma alma? Todos são enobrecidos pela mesma nobreza, todos são servos da mesma servidão, todos são livres com a mesma liberdade. Ali você encontrará a mesma riqueza para todos, não em teoria, mas na realidade. Um prazer, um desejo, uma esperança para todos. De fato, tudo é perfeitamente regulado como se por uma norma e regra. Aí não há desigualdade, mas ordem, proporção, harmonia, concordância profunda e exata e motivos constantes de contentamento. Somente neste tipo de vida alguém pode ver isso acontecer perfeitamente, em nenhum outro lugar (Adv. oppug., III, 11).

João Crisóstomo constrói aqui a imagem do mosteiro como um refúgio diante dos perigos e incertezas do mundo, como um ambiente no qual prevaleceriam a harmonia, a solidariedade e a igualdade, em contraste com a injustiça e a competição próprias da cidade, na qual seria muito difícil para uma criança crescer. No mosteiro, seria permitido ao menino viver uma vida ao mesmo tempo confortável, serena e alegre, na companhia de seres tidos como celestiais, o que favoreceria sua elevação espiritual. O mosteiro se tornaria uma segunda família unida pelos valores cristãos, em substituição à família consanguínea, de maneira que as comunidades monásticas foram tidas, em geral, como novas células familiares nas quais os superiores desempenhavam as funções parentais, ao passo que os seus membros se viam como irmãos, não sendo por acaso que o título 
mais comum atribuído, no início, aos monges mais idosos e, mais tarde, aos abades foi o de abbas, ou seja, o de pai. Dentre o conjunto de renúncias exigidas a um aspirante ao noviciado ou mesmo a alguém que fosse entregue ao mosteiro para ser educado, uma das mais frequentes era a renúncia aos laços familiares, o que incluía tanto o casamento quanto o contato regular com os demais parentes, embora não fosse incomum que dois ou mais membros de uma mesma família coabitassem num mosteiro (TALBOT, 1990, p. 121). Seja como for, segundo João Crisóstomo, a educação da criança implicava ao mesmo tempo uma ruptura com a cidade e com o núcleo familiar mediante a internação, por período indefinido, num dos mosteiros erguidos no deserto ou na montanha que começavam, na segunda metade do século IV, a se multiplicar em Antioquia e arredores.

\section{Considerações finais}

A proposta pedagógica formulada por João Crisóstomo para os filhos da elite de Antioquia fundamentava-se, como vimos, no elogio da vida monástica, uma vez que o autor, ao retornar do seu treinamento ascético no Monte Sílpios, encontrava-se imbuído dos ideais característicos do monacato, desejando assim difundi-los entre os estratos superiores da cidade, que deveriam confiar a educação dos filhos aos monges. Na avaliação de Hunter (1988, p. 17), após o retorno, João Crisóstomo não cultivava mais a percepção ingênua ou acrítica do monacato que havia marcado seus anos de juventude, antes de ele próprio se converter num asceta e se submeter às mais rudes provações corporais, como revela uma passagem contida no De sacerdotio $(6,5-7)$, um tratado sobre o ofício sacerdotal escrito durante os seus anos de diaconato, mas certamente posterior ao Adversus oppugnatores, no qual o autor valoriza a posição do bispo, em detrimento da do monge. Muito embora essa mudança de opinião seja uma realidade, não resta dúvida que, ao longo de toda a sua carreira, João jamais deixou de cultivar os valores monásticos, assim como também nunca abriu mão de criticar a escola clássica, ainda que deva sua habilidade em retórica aos ensinamentos que dela recebeu. Diante disso, ao contrário de Talbot (1990, p. 147), não consideramos o Adversus oppugnatores muito mais uma apologia da vida ascética do que um tratado sobre a melhor educação das crianças, uma vez que ambos os temas se sobrepõem no pensamento de João, para quem enaltecer os monges e reconhecer o papel dos mosteiros na socialização infantil equivalia a erodir os fundamentos da paideia. Como bem observa Hare (1974, p. 101-102), João nutria pouca simpatia pela educação retórica, tendo feito um esforço deliberado para substituí-la por uma formação calcada nas Escrituras e supervisionada pelos monges, na qual se enfatizavam as virtudes morais, de acordo com os princípios da filosofia, ou seja, 
da arte de bem viver. Quanto a isso, discordamos também da opinião de Leroux (1975, p. 141), segundo a qual João Crisóstomo não pode ser considerado um iniciador das escolas monásticas. Decerto, João nunca fundou uma instituição desta natureza, mas seus argumentos referendavam uma alternativa de formação educacional para as crianças que começava a tomar forma nas últimas décadas do século IV, num momento em que os cristãos eram chamados a apresentar suas próprias soluções para a vida em sociedade, muitas delas formuladas em oposição ao modus vivendi greco-romano, o que incluía a implementação de uma nova proposta de educação das crianças e jovens.

\section{Referências}

\section{Documentação textual}

A BÍBLIA DE JERUSALÉM. Edição coordenada por Gilberto Gorgulho, Ivo Storniolo e Ana Flora Anderson. São Paulo: Sociedade Bíblica Católica Internacional, 1997.

AMMIANUS MARCELLINUS. History: books 20-26. Translated by John C. Rolfe. Cambridge: Harvard University Press, 2006.

JOHN CHRYSOSTOM. A comparison between a king and a monk. Against the opponents of the monastic life. Translated with an introduction by David. G. Hunter. Lewiston: The Edwin Mellen Press, 1988.

PHARR, C.; DAVIDSON, T. S. (Ed.). The Theodosian Code and novels, and Sirmondian Constitutions. Princeton: Princeton University Press, 1952.

ST. JOHN CHRYSOSTOM. On the priesthood. In: SCHAFF, P. (ed.) Nicene and post-Nicene Fathers. Translation and notes by W. R. W. Stephens. Peabody: Hendrickson, 2004, p. 33-83. t. IX.

TEODORETO DE CIRO. Historia de los monjes de Siria. Introducción, traducción y notas de Ramón Teja. Madrid: Trotta, 2008.

\section{Obras de apoio}

ARIÈS, P. História Social da criança e da família. Rio de Janeiro: Guanabara, 1978.

BAKER, D. A. Syriac and the origins of monasticism. Sage Journals, v. 86, i. 285, p. 342-353, 1968.

BLOOMER, M. Becoming a Roman student. In: LAES, C.; VUOLANTO, V. (ed.). Children and everyday life in the Roman and Late Antique world. London: Routledge, 2017, p. 166-176. 
BLOOMER, M. The ancient child in school. In: GRUBBS, J. E.; PARKIN, T.; BELL, R. (ed.). The Oxford handbook of childhood and education in the Classical World. Oxford: Oxford University Press, 2013, p. 444-459.

BROCK, S. P. Early Syrian asceticism. Numen, v. 20, fasc. 1, p. 1-19, 1973.

CASEAU, B. Resistance and agency in the everyday life of Late Antique children (thirdeighth century CE.). In: LAES, C.; VUOLANTO, V. (ed.). Children and everyday life in the Roman and Late Antique world. London: Routledge, 2017, p. 217-231.

CRIBIORE, R. Gymnastics of the mind: Greek education in Hellenistic and Roman Egypt. Princeton: Princeton University Press, 2001.

DZIELSKA, M. Hipátia de Alexandria. Lisboa: Relógio d'Água, 2009.

FESTUGIÈRE, A. J. Antioch païenne et chrétienne: Libanius, Chrysostome et les moines de Syrie. Paris: de Boccard, 1959.

GIORDA, M. C. Children in monastic families in Egypt at the end of Antiquity. In: LAES, C.; VUOLANTO, V. (ed.). Children and everyday life in the Roman and Late Antique world. London: Routledge, 2017, p. 232-246.

HARE, B. W. St. John Chrysostom on education. Prudentia, n. 6, p. 99-104, 1974.

HULL, D. A spatial and morphological analysis of monastic sites in the Northern Limestome Massif, Syria. Levant, n. 40, i. 1, p. 89-113, 2016.

JONES, A. H. M. John Chrysostom's parentage and education. The Harvard Theological Review, v. 46, n. 3, p. 171-173, 1953.

KELLY, J. N. D. Golden Mouth: John Chyrsostom, ascetic, preacher, bishop. Ithaca: Cornell University Press, 1995.

KNAPP, R. Invisible Romans. Cambridge: Harvard University Press, 2011.

KRAWIEC, R. Asceticism. In: HARVEY, S. A.; HUNTER, D. G. (ed.). The Oxford handbook of Early Christian studies. Oxford: Oxford University Press, 2008, p. 764-785.

LAES, C.; VUOLANTO, V. A new paradigm for the social history of childhood and children in Antiquity. In: LAES, C.; VUOLANTO, V. (ed.). Children and everyday life in the Roman and Late Antique world. London: Routledge, 2017, p. 1-9.

LAl, P. W. The monk as Christian saint and exemplar in St John Chrysostom's writings. Studies in Church History, n. 47, p. 19-28, 2011.

LEBRUN, G. Philipe Ariès. In: SALES, V. (org.). Os historiadores. São Paulo: Editora Unesp, 2011, p. 225-244.

LEROUX, J. M. Saint Jean Chrysostome el le monachisme. In: KANNENGIESSER, Ch. (éd.). Jean Chysostome et Augustin. Paris: de Boccard, 1975, p. 125-144. 
LEYERLE, B. Children and "the child" in Early Christianity. In: GRUBBS, J. E.; PARKIN, T.; BELL, R. (ed.). The Oxford handbook of childhood and education in the Classical World. Oxford: Oxford University Press, 2013, p. 559-579.

LIEBESCHUETZ, J. H. W. G. Ambrose \& John Chrysostom: clerics between desert and empire. Oxford: Oxford University Press, 2011.

MARROU, H. I. História da Educação na Antiguidade. São Paulo: EPU, 1990.

PRICE, R. M. Introduction. In: THEODORET OF CYRRHUS. A history of the monks of Syria. Collegeville: Cistercian Publications, 1985, p. ix-xxxvii.

RUBENSON, S. Asceticism and monasticism. In: NOBLE, T.; SMITH, J. (ed.). The Cambridge History of Christianity. Cambridge: Cambridge University Press, 2008, p. 673-668.

SCHMITT, J. C. História dos Marginais. In: LE GOFF, J. (ed.). A História Nova. São Paulo: Martins Fontes, 1990, p. 261-290.

SHARPE, J. A história vista de baixo. In: BURKE, P. (org.). A escrita da História. São Paulo: Editora Unesp, 1992, p. 39-62.

SILVA, G. V. Conflito religioso e simbolismo arquitetônico na Antiguidade Tardia: o ataque aos templos pagãos segundo Libânio de Antioquia. Calíope, n. 27, p. 45-72, 2014.

SILVA, G. V. A formação dos cidadãos do céu: João Crisósotomo e a Christon paideia. Acta Scientiarum Education, v. 32, n. 1, p. 7-17, 2010.

SILVA, G. V. Prisioneiras do esquecimento: a representação das mulheres nos livros didáticos de História. Dimensões, n. 23, p. 45-66., 2009.

TALBOT, A. M. The Byzantine family and the monastery. Dumbarton Oak Papers, v. 44, p. 119-129, 1990.

VAINFAS, R. Micro-história: os protagonistas anônimos da história. Rio de Janeiro: Campus, 2002.

VUOLANTO, V. Experience, agency, and the children in the past. In: LAES, C.; VUOLANTO, V. (ed.). Children and everyday life in the Roman and Late Antique world. London: Routledge, 2017, p. 11-24.

VUOLANTO, V. Children in the Roman World: cultural and social perspectives. A review article. Arctos, n. 48, p. 435-450, 2014.

VUOLANTO, V. Elite children, socialization, and agency in the Late Roman World. In: GRUBBS, J. E.; PARKIN, T.; BELL, R. (ed.). The Oxford handbook of childhood and education in the Classical World. Oxford: Oxford University Press, 2013, p. 580-599.

WATTS, E. Education: speaking, thinking, and socialization. In: JOHNSON, S. F. (ed.). The Oxford handbook of Late Antiquity. Oxford: Oxford University Press, 2012, p. 467486. 